\title{
Direct Teacher Corrective Feedback in EFL Writing Class at Higher Education: What Students Perceive
}

\author{
Sabarun \\ English Department of IAIN Palangka Raya \\ sabarun@ iain-palangkaraya.co.id
}

\begin{abstract}
The study is aimed at describing the students' perception of direct teacher corrective feedback in a foreign language writing class. It is descriptive quantitative research, employing questionnaires and observation as research instruments, which was conducted with 20 students of the fourth semester English department students of Palangka Raya State Islamic Institute of 2018/ 2019 academic year. The findings revealed that, firstly, in terms of the perception of students' attitudes toward direct teacher corrective feedback, 75 percent of participants felt that they agreed to receive direct teacher corrective feedback on language form, content, and organization. Their preference for the area of corrective feedback in language forms was 85 percent while the organization was 65 percent. Secondly, dealing with the students' perception on direct teacher feedback, 90 percent of students argued that they felt satisfied when they got direct teacher feedback. 85 percent of students perceived that their teacher's feedback helped them improve their writing, and 90 percent of them realized that their teacher's feedback made them feel confident in producing a better draft. Finally, most students responded that they appreciated the teacher's feedback. In addition, the students believed that direct teacher feedback improved writing especially on grammar accuracy and organization.
\end{abstract}

\section{ARTICLE HISTORY}

Received 23 November 2019

Accepted 27 February 2020

\section{KEYWORDS}

direct teacher feedback; students' perception; writing

\section{Introduction}

Despite the fact, that many researchers are interested in investigating corrective feedback in second or foreign language writing, there is still a limited number of those investigating corrective feedback in the Kalimantan higher education context since there are many higher education institutions in the region. Giving corrective feedback in second or foreign language writing is very important in the language learning process (Sato \& Lyster, 2012). It enables language instructors to give more information on the accuracy of students' writing performance by increasing awareness of the grammatical errors of the writing. One of the types of feedback which is widely used for students' composition is Direct Teachers' Corrective Feedback (hereafter, DTCF). Different types of direct corrective feedback had been found effective for the teaching and learning process, such as on the correct use of 
English articles, which was an important part of writing, among EFL students (Soori, Kafipour, \& Soury, 2011). Oler (2015), on the other hand, posited that age and proficiency level are variables, which affect these attitudes and preferences, while Vyatkina (2011) found that feedback on holistic aspects was expanding. Evidence on direct written corrective feedback has been studied by Ellis (2009), Sheen (2007), and Ferris \& Roberts (2001). Clements (2011) suggested that a direct method in providing feedback does not tend to have results which are commensurate with the effort needed from the teachers to draw the students' attention to surface errors because it does not give students an opportunity to think or to do anything.

Identification of the implementation of corrective feedback is as crucial as how students perceive it. There are some studies that explore the influence of perception on corrective feedback (Kartchava, 2016; Vyatkina, 2011; Jodaie, Farrokhi, \& Zoghi, 2011; Rejab, Ismail, \& Jamaludin, 2015), and learners' beliefs about corrective feedback perspectives from different contexts (Kartchava, 2016). Teachers' perception does not coincide with what students expect from their teachers in which Martinez Buffa (2016) captured teachers must assess students' expectations regarding written corrective feedback by knowing preferences that can be beneficial for both parties. Furthermore, Rejab et al., (2015) argued that teacher may provide feedback in verbal, written and nonverbal forms. Evans, Hartshorn, \& Allen Tuioti, (2010) stated that knowing teachers' views on corrective feedback is also essential to understand the place of written corrective feedback in second or foreign language writing pedagogy and written corrective feedback implemented by English as Foreign Language (EFL) teachers. However, since their study was based on respondents' self-reporting, it was necessary to examine the written corrective feedback through the external measure. Besides, all of the studies mentioned above focus on teachers' views while students' perspectives were investigated in an international context. The students' perception of DTCF in EFL writing, especially in argumentative writing, at higher education settings is not explored and identified explicitly so this study is conducted to address this gap.

\section{Literature Review}

Perception is the procedure of recognizing, organizing, and interpreting information to give meaning to the environment. Therefore, it is necessary to review the learners' perception on teacher direct written corrective feedback in order to have further knowledge on the implementation of direct teacher corrective feedback. Studies on perception have been conducted (Amara, 2015; Westmacott, 2017; Mahfoodh \& Pandian, 2011; Erkkilä, 2013; Tangkiengsirisin \& Kalra, 2016; and Chung, 2015). First, EFL learners had a strong interest in teacher comments, appreciated the feedback, and misinterpreted some teacher feedback comments (Amara, 2015). The study has significantly developed knowledge of learners' perceptions, most students 
in this L2 class stated indirect feedback was more helpful and it was proved that it might also help strengthened grammar skills and motivate self-learning behavior (Westmacott, 2017). Furthermore, Mahfoodh \& Pandian (2011) suggested that students perceived their teachers' written feedback as useful, very crucial for language accuracy. Moreover, Erkkilä (2013) and Tangkiengsirisin \& Kalra (2016) provided different systems of error and feedback categorization to help research the properties of language teachers' feedback outcome in student papers, and Chung (2015) indicated that Korean EFL learners react in favor of direct feedback to their written work, and yet they show little tolerance for simply marking the error without explanation or no feedback.

Direct feedback was a procedure to provide students with explicit information and guidance to correct errors directly (Ellis, 2009). Moreover, Ferris \& Roberts (2001) suggested that direct corrective feedback was suitable for students with a low level of writing skill. Here, the writer views direct feedback as a model of feedback where teachers provide the students with the true form directly, such as in correcting students work with direct feedback by adding the letter of s after the word apple in the sentence of "She has three apples". Teachers' written feedback, however, is a complex area, and several studies have dealt with it from different angles. Clements (2011), for example, have investigated the methods (e.g., direct correction, the use of codes, etc.) that teachers utilize to respond their students' written work. Direct teacher corrective feedback simply means that the teacher provides the students with the correct form of their errors or mistakes orally or written. The feedback shows them what is wrong and how to write the correct sentence, but it leaves no work and chance for them to think what the errors and the mistakes are.

\section{Method}

The design in the study was descriptive quantitative research since the study focused on investigating the students' perception of DTCF in EFL writing class. Williams, (2007) stated that descriptive research was a research that was purposeful for describing, explaining, and interpreting collected data. The study also employed quantitative methods to describe the students' perception on feedback in EFL writing class. The qualitative data were needed to cover a deeper understanding on learners' attitudes on using direct teacher's feedback in the classroom setting.

This study was restricted on the students' perception on DTCF in EFL writing. The result of this study became the basis to implement DTCF in EFL writing class that focused on the argumentative essay as proposed by (Smalley, Ruetten, \& Kozyrev, 2012). Meanwhile, teacher Corrective Feedback applied in this study was direct CF as proposed by (Ellis, 2009). In line with the source of feedback, the researcher used teacher CF as proposed by (D. Ferris \& Bitchener, 2012). 


\section{Participants and Setting}

The research was conducted at the English Study Program of Palangkaraya State Islamic Institute (IAIN Palangka Raya). The subjects of the study were the fourthsemester students of the academic year 2018/2019. Meanwhile, the object of the study was DTCF in EFL writing class. The participants consisted of 20 students of Argumentative Essay Writing class (4 males and 16 females) with an average age between 20-21 years, participating in Argumentative Essay Writing class where they learned corrective feedback as a part of learning materials. The present study had a purposive sampling in which the participants were chosen based on predetermined criteria.

\section{Procedures}

The data were collected in several meetings during one semester. The data of this study were in the form percentage, words, sentences, or paragraphs to describe the students' perception on DTCF in EFL writing class. The types of data were in the form of qualitative and quantitative data. The quantitative data dealt with the percentage of the learners' perception on DTCF in EFL writing class. Meanwhile, the qualitative data dealt with the further explanation of students' perception on DTCF in EFL writing class. Qualitative data collection and analysis enabled the researcher to understand and interpret the students' perception on DTCF in EFL writing class. The instrument used in this study was a questionnaire. The questionnaire was designed into three parts. The first part included questions to get demographic information, namely name, age, gender, and email contact. The second part was to find out the students' perception on DTCF in EFL writing class. The second part consisted of 14 statements in a 4-point Likert Scale format, anchored by strongly agree (SA), agree (A), disagree (D) and strongly disagree (SD). The items were originally directed towards students' underlying constructs regarding (a) students' perception on direct teacher feedback; and (b) perception on students' feelings toward receiving direct teacher's corrective feedback. Meanwhile, there were also 5 open-ended questions that should be responded by the participants. The questions covered students' perceptions towards direct teacher's corrective feedback.

\section{Results and Discussion}

The study investigated students' perceptions towards direct teacher corrective feedback in EFL writing, whether they found them useful and which strategy the students preferred the most. To answer the research problem about the students' perception, the researcher distributed the questionnaire to the participants. The 
questionnaire showed that participants were asked about how their perception on teacher written corrective feedback. Dealing with statement 1 , I receive direct teacher corrective feedback $(C F)$ on language form; The participants gave responses, as illustrated in Figure 1.

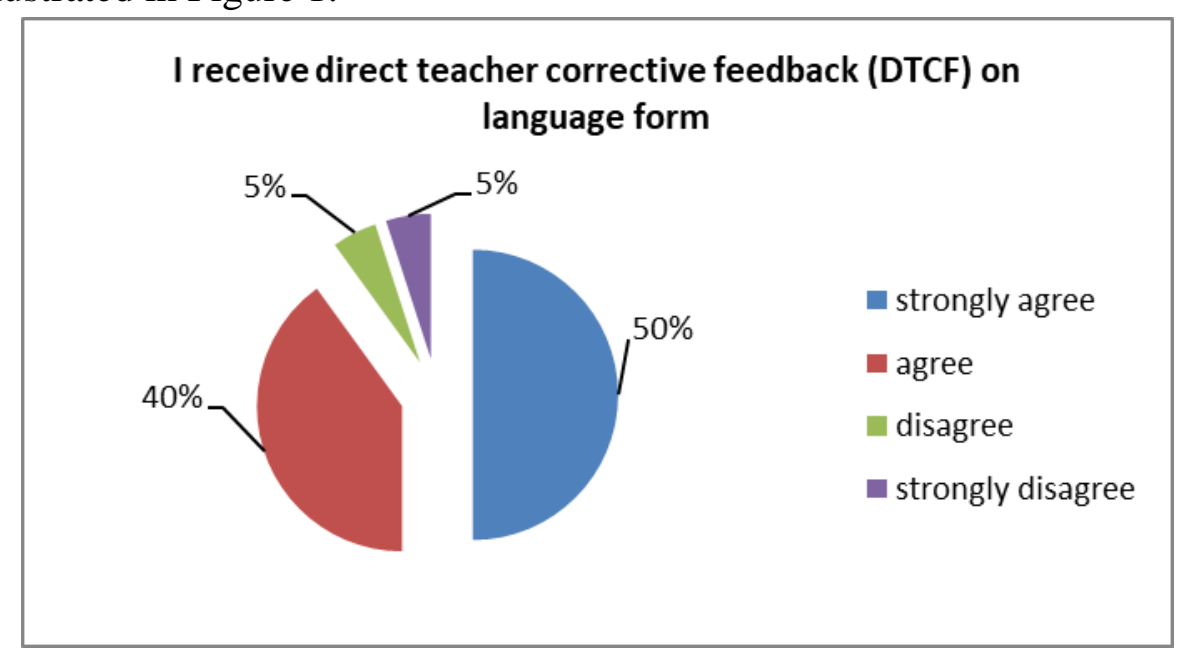

Figure 1. I receive direct teacher corrective feedback (DTCF) on language form

Based on the output above, it was found that 18 out of 20 respondents or $90 \%$ stated that they received direct teacher corrective feedback (DTCF) on language form. The number of students who showed their agreement with statement one is 18 . Only 2 students disagree with the statement. This indicated that students had positive perceptions towards the teacher's way of correcting their writing in terms of language forms. This result was in accordance with a study carried out by Mahfoodh \& Pandian (2011) about student's affective reactions to their teachers' feedback. His findings indicated that EFL students like the teacher's written feedback because they considered the teacher's correction to develop their writing skills and improve their future written texts.

Dealing with statement 2, I receive direct teacher corrective feedback (DTCF) on content, the participants gave a different response, as illustrated in Figure 2.

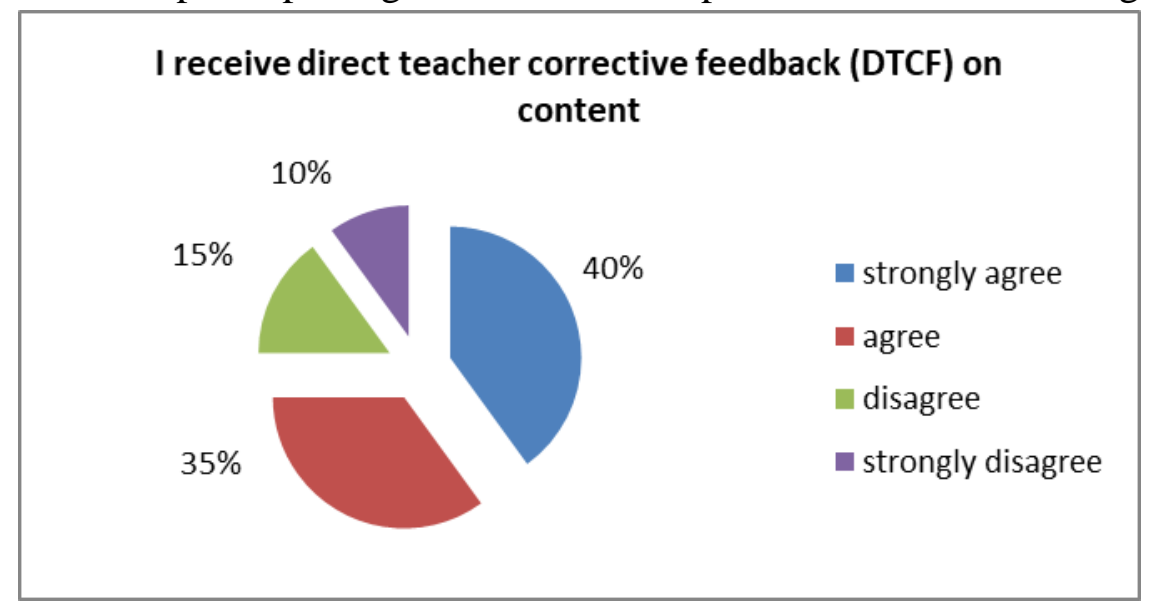

Figure 2. I receive direct teacher corrective feedback (DTCF) on content 
Based on the output, it was clear that the majority of the respondents (75\%) stated that they received direct teacher corrective feedback (DTCF) on content." There were 15 students who agree to the statement and only 5 students did not agree. The number of students who showed their agreement with statement 2 was 15 . Only 5 out of 20 students disagreed with the second statement. This indicated that students had positive perceptions towards the teacher's way of correcting their writing in terms of content.

Dealing with statement 3 , I receive direct teacher corrective feedback (DTCF) on the organization; the participants gave a different response, as illustrated in Figure 3.

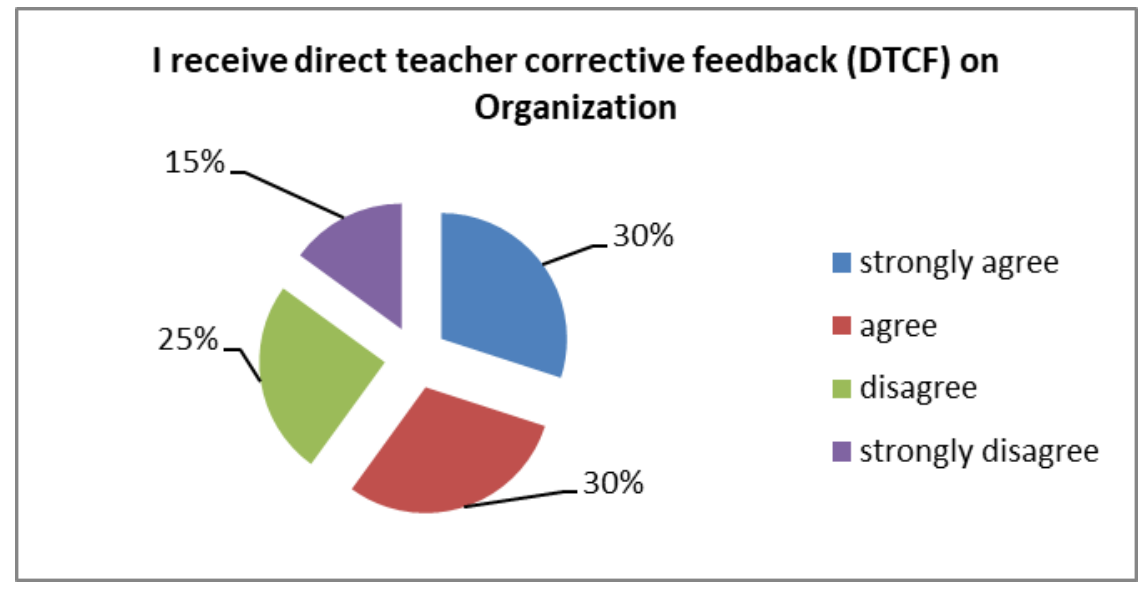

Figure 3. I receive direct teacher corrective feedback (DTCF) on organization

Based on the output, it was clear that part of the respondents $(60 \%)$ stated that they received direct teacher corrective feedback (DTCF) on the organization." There were 12 students agree to the statement and 8 students (40\%) did not agree. The number of students who showed their agreement with statement 3 was 12 . 8 out of 20 students disagreed with the third statement. As can be seen from Figure 3, more than half of the students were satisfied with the teacher's feedback on their writing assignments in terms of organization. This indicated that students had positive perceptions towards the teacher's way of correcting their writing in terms of organization.

Based on the data above, it was said that dealing with the perception on learners' attitudes toward receiving direct teacher feedback, the majority of participants $(75 \%)$ felt that they agreed to receive direct teacher corrective feedback on language form, content, and organization. Their preference on the area of correction was in language forms $(85 \%)$, and the less area of correction was in the organization $(65 \%)$.

The next step was to describe the perception on students' feelings toward receiving direct teacher corrective feedback. From questionnaire results, participants were asked about how their feeling when receiving teacher written corrective feedback. 
Dealing with statement 4, I feel satisfied when I get my teacher's feedback; the participants gave responses, as illustrated in Figure 4.

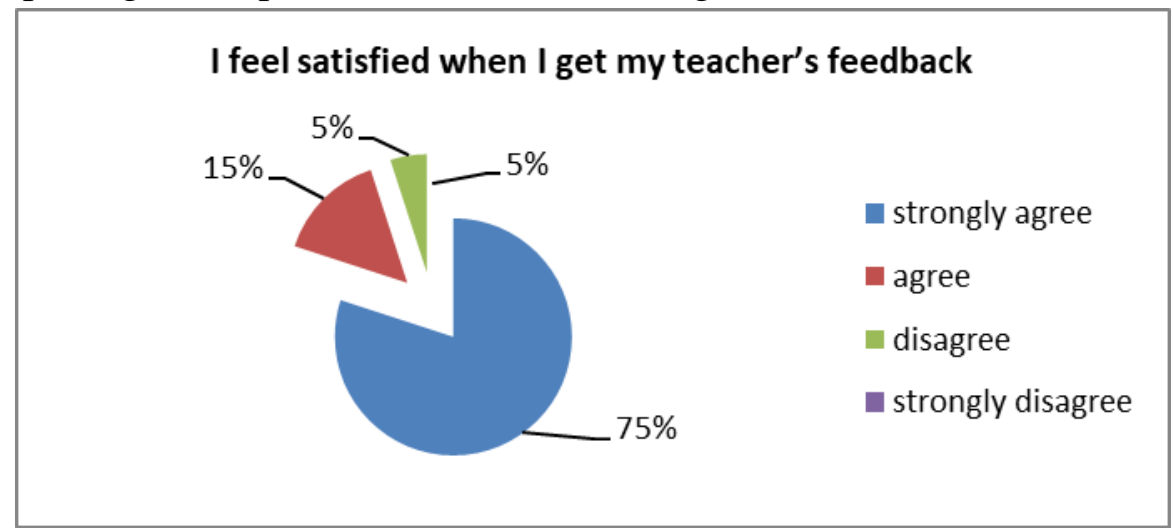

Figure 4. I feel satisfied when I get my teacher's feedback

Based on the output above, it was found that 18 out of 20 respondents or $90 \%$ stated that they felt satisfied when they got their teacher's feedback. The number of students who showed their agreement with statement number 7 was 18 , and only 2 students or $(10 \%)$ did not feel satisfied when they got their teacher's feedback. It meant that the majority of students felt satisfied when they got their teacher's feedback on their writing assignments. This indicated that students had good perceptions towards the teacher's way of correcting their writing.

Dealing with statement 5, I prefer to get feedback than no feedback; the participants gave responses, as illustrated in Figure 5.

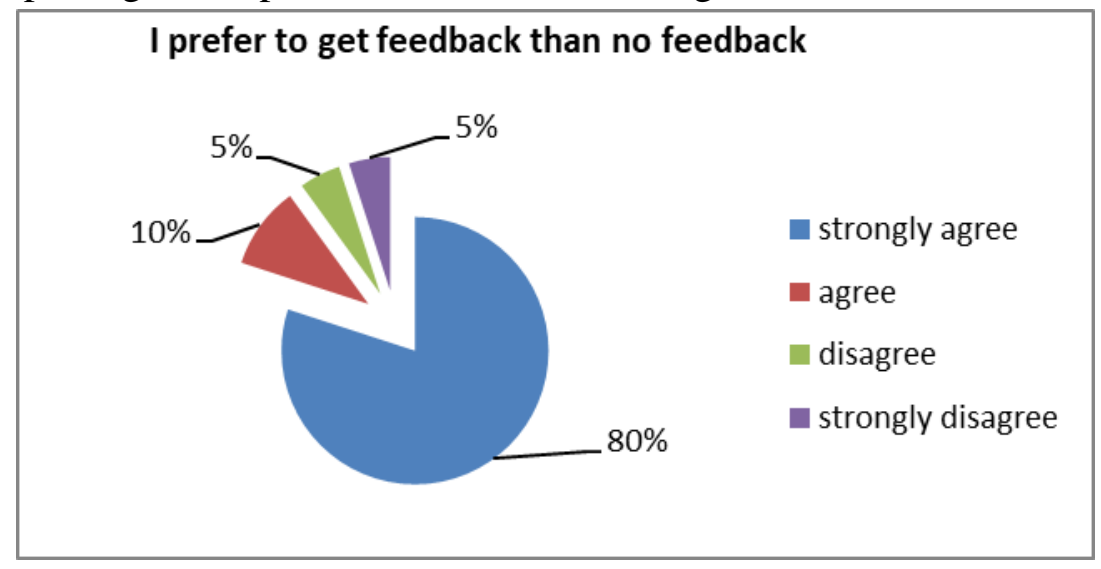

Figure 5. I prefer to get feedback than no feedback

Based on the output above, it was found that 18 out of 20 respondents or $90 \%$ stated that they preferred to get feedback than no feedback. The number of students who showed their agreement with statement number 8 was 18 , and only 2 students or $(10 \%)$ did not prefer to get feedback than no feedback feel. It meant that the majority of students preferred to get feedback than no feedback on their writing assignments.

Regarding statement 6, my teacher's feedback helps me improve my writing; the participants gave responses, as illustrated in Figure 6. 


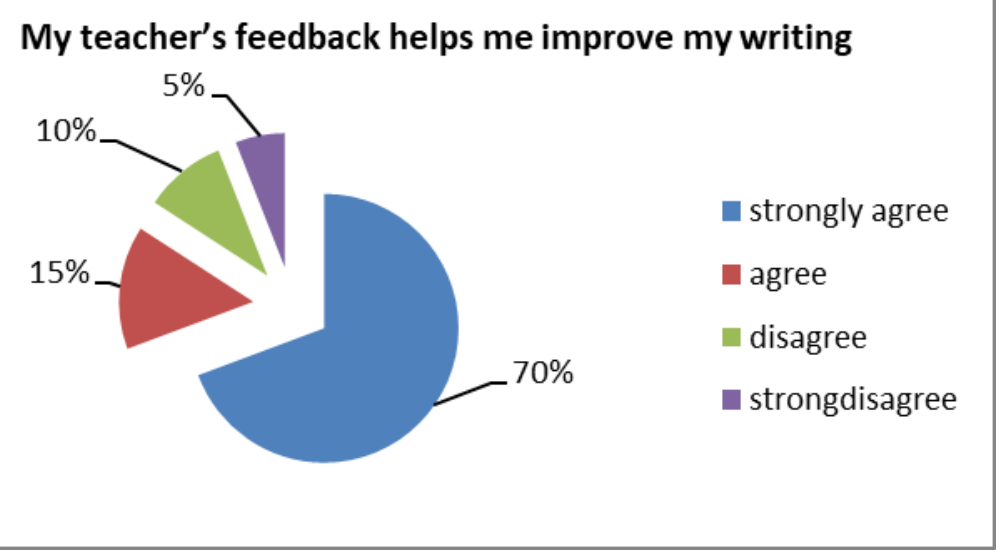

Figure 6. My teacher's feedback helps me improve my writing

Based on the output above, it was found that 17 out of 20 respondents or $85 \%$ stated that their teacher's feedback helps them improve their writing. The number of students who showed their agreement with statement number 9 was 17 , and only 3 students or $(15 \%)$ did not agree that their teacher's feedback helps them improve their writing. It meant that the majority of students felt that their teacher's feedback helps them improve their writing.

Dealing with statement 7, I feel assessed when I get my teacher's feedback; the participants gave responses, as illustrated in Figure 7.

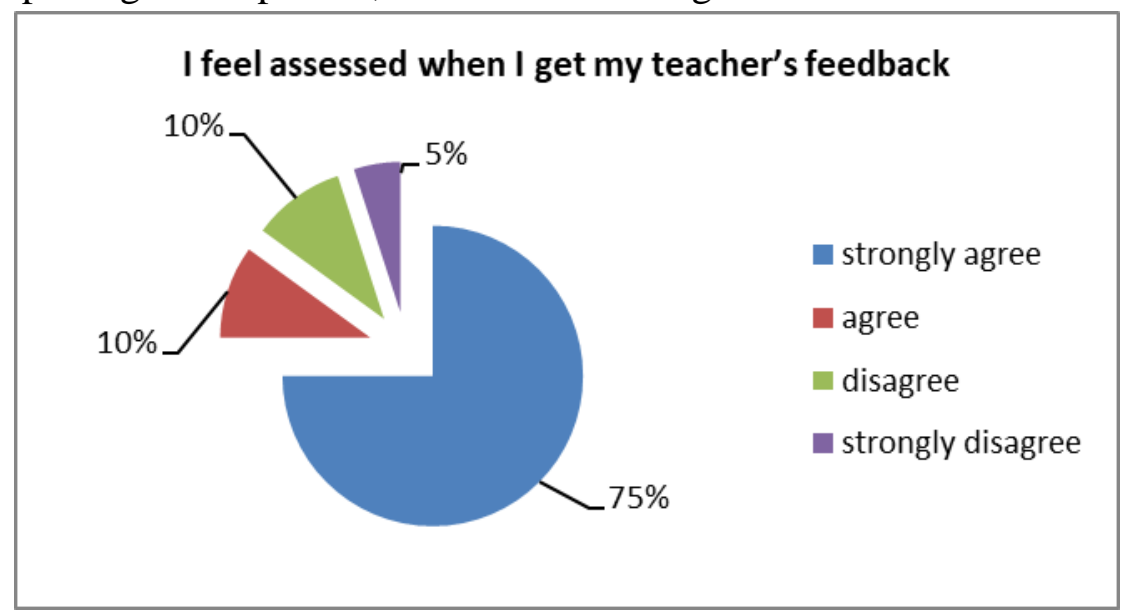

Figure 7. I feel assessed when I get my teacher's feedback

Based on the output above, it was found that 17 out of 20 respondents or $85 \%$ stated that they felt assessed when they got their teacher's feedback. The number of students who showed their agreement with statement number 10 was 17, and only 3 students or $(15 \%)$ did not agree that they assessed when they got their teacher's feedback. It meant that the majority of students felt assessed when they got their teacher's feedback.

Dealing with statement 8 , my teacher's feedback makes me feel unwilling to do the task again; the participants gave responses, as illustrated in Figure 8. 


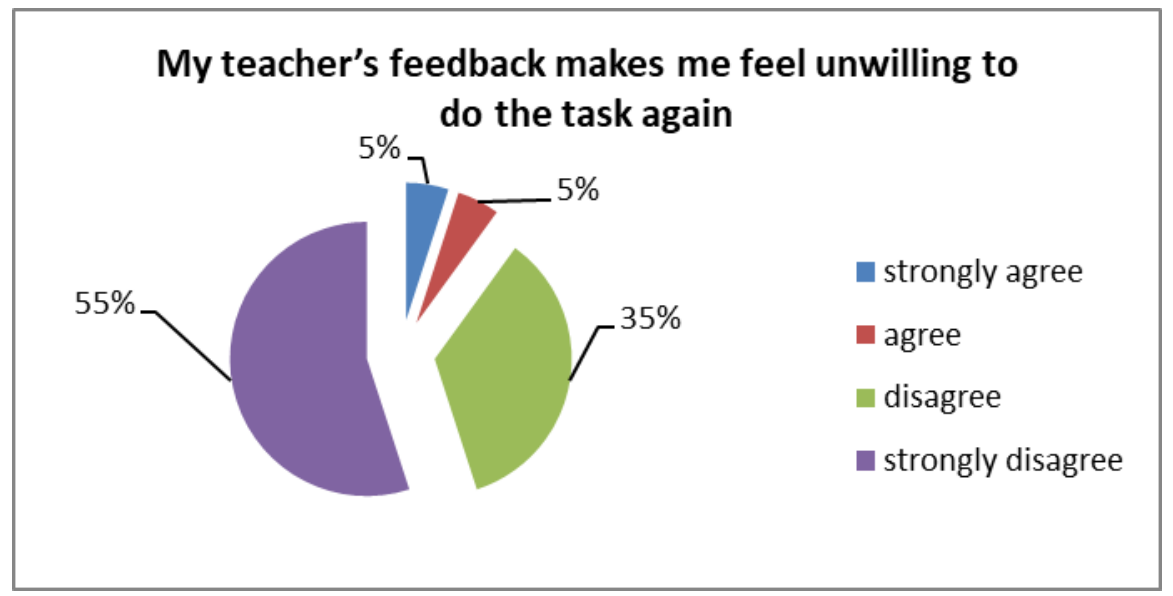

Figure 8. My teacher's feedback makes me feel unwilling to do the task again

Based on the output above, it was found that 18 out of 20 respondents or $90 \%$ stated that their teacher's feedback did not make them felt unwilling to do the task again. The number of students who showed their disagreement with statement number 11 was 18 , and only 2 students or (10\%) agreed that their teacher's feedback made them felt unwilling to do the task again. It meant that the majority of students felt that their teacher's feedback made them felt willing to do the task again.

Dealing with statement 9, My teachers' feedback makes me confident of producing a better draft; the participants gave responses, as illustrated in Figure 9.

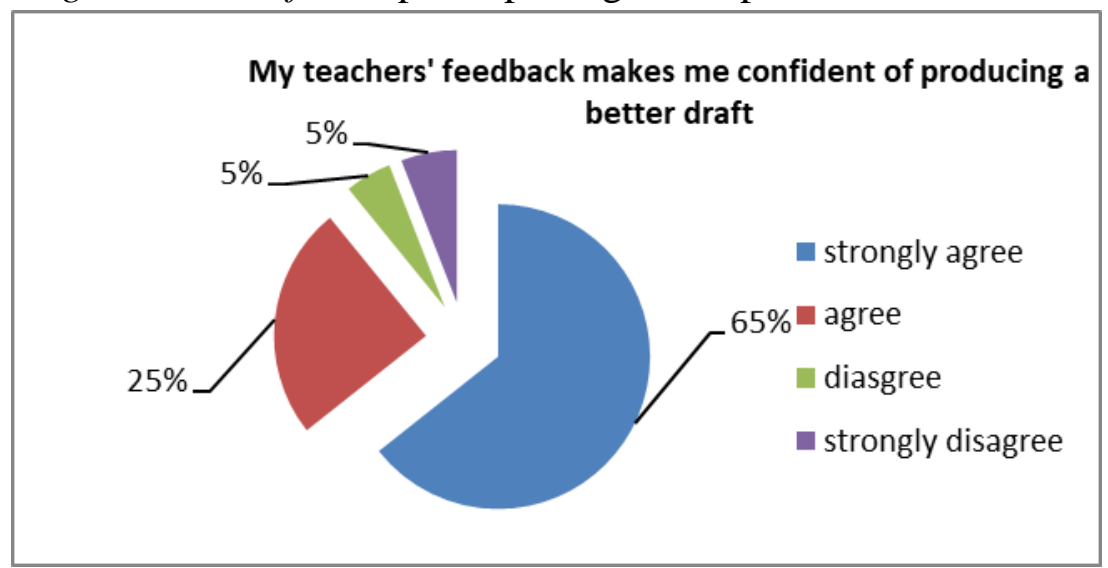

Figure 9. My teachers' feedback makes me confident of producing a better draft

Based on the output above, it was found that 18 out of 20 respondents or $90 \%$ stated that their teacher's feedback made them the confidence of producing a better draft. The number of students who showed their agreement with statement number 12 was 18 , and only 2 students or $(10 \%)$ did not agree with it. It meant that the majority of students felt that their teacher's feedback made them the confidence of producing a better draft.

Dealing with statement 10, I prefer the teacher just corrects directly the error without underlining it; the participants gave responses, as illustrated in Figure 10. 


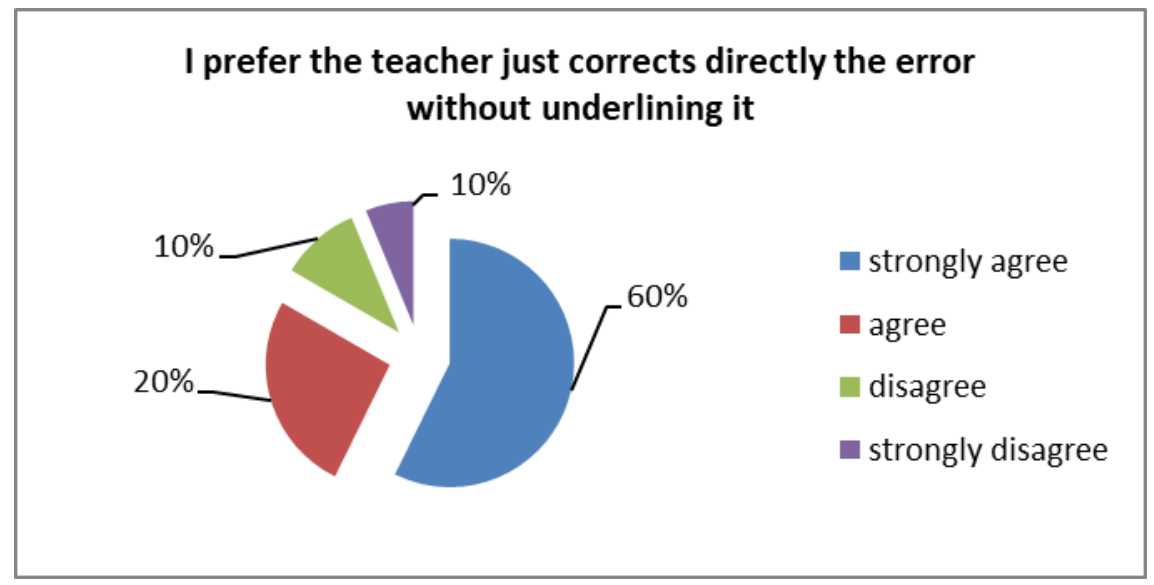

Figure 10. I prefer the teacher just corrects directly the error without underlining it

Based on the output above, it was found that 16 out of 20 respondents or $80 \%$ stated that they prefer their teacher to just correct directly the error without underlining it. The number of students who showed their agreement with statement number 13 was 16, and only 4 students or (20\%) showed their disagreement. It meant that the majority of students prefer their teacher corrects directly the error without underlining it.

Dealing with statement 11, I prefer to discuss my errors with my teachers in his office or outside the classroom; the participants gave responses, as illustrated in Figure 11.

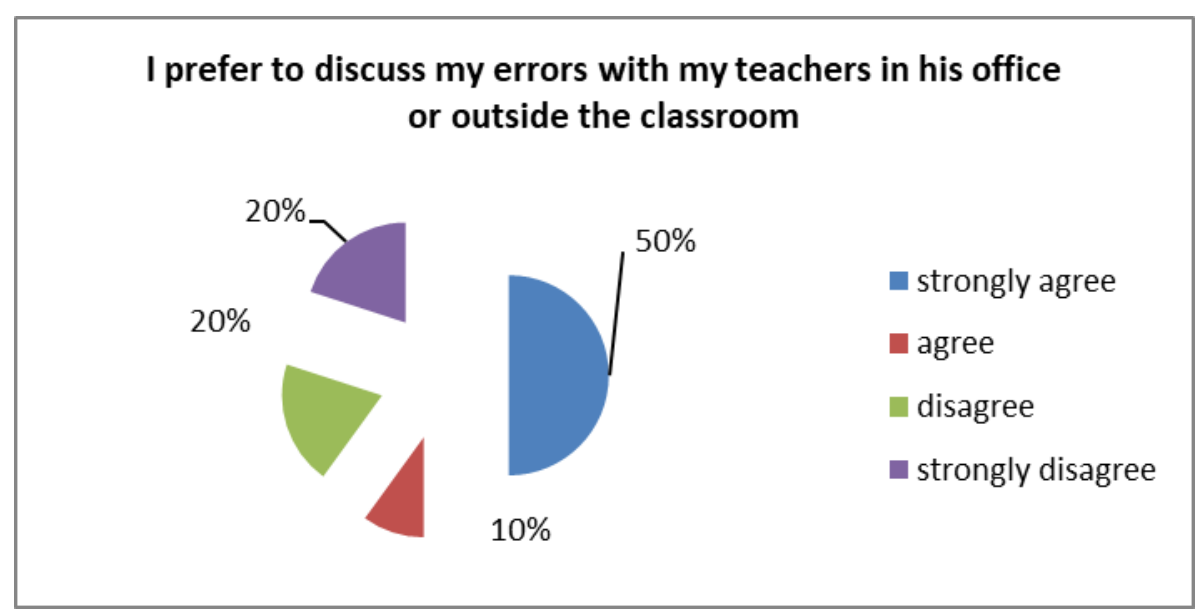

Figure 11. I prefer to discuss my errors with my teachers in his office or outside the classroom

Based on the output above, it was found that 12 out of 20 respondents or $60 \%$ stated that they prefer to discuss their errors with their teacher in his/her office or outside the classroom. The number of students who showed their agreement with statement number 14 was 12 , and only 8 students or (40\%) showed their disagreement. It meant that many students prefer to discuss their errors with their teacher in his/her office or outside the classroom. 
Based on the output above, it was that most students believed that it was important to receive direct teacher feedback, arguing that they felt satisfied when they got direct teacher feedback (90\%), they preferred to get feedback than no feedback (90\%), their teacher's feedback helped them improved their writing (85\%), they felt assessed when they got teacher's feedback (85\%), and their teacher's feedback made them confident of producing a better draft (90\%).To sum up, the learners' responses suggested that they appreciated teacher corrective feedback and had a positive attitude on the teacher's feedback. The EFL learners claimed that they got benefit from teacher corrective feedback on language forms and they preferred to direct feedback than others.

The findings of the students' perception towards written corrective feedback were related to two important issues, namely to student attitudes towards their teacher's feedback and the students' feeling towards their teacher's feedback. First, the findings demonstrated that the majority of participants (75\%) felt that they agreed to receive direct teacher corrective feedback on language form, content, and organization. Their preference for the area of correction was in language forms $(85 \%)$, and the less area of correction was in the organization (65\%). Second, dealing with the perception on students' feelings toward receiving direct teacher feedback, it was found that most students believed that it was important to receive direct teacher feedback, arguing that they felt satisfied when they got direct teacher feedback (90\%), they preferred to get feedback than no feedback (90\%), their teacher's feedback helped them improved their writing $(85 \%)$, they felt assessed when they got teacher's feedback (85\%), and their teacher's feedback made them confident of producing a better draft $(90 \%)$. Third, responses also showed that students, in general, appreciated the teacher's feedback and had a positive attitude towards written corrective feedback. Students' responses showed their preference for direct written corrective feedback. Students considered written feedback helpful and useful for their improvement in writing. The students believed that direct feedback in general improved writing, especially on grammar accuracy and organization.

The results were in accordance with other studies investigating students' attitudes and beliefs about feedback. For example, Mustafa (2012) found that L2 learners preferred to receive feedback on a variety of writing aspects rather than feedback focusing on grammar. This finding was also in line with the research conducted by (Hamouda, 2011). She found that nearly half of the students preferred direct feedback and it could help to address the problems as it was easy to identify their errors and improve their accuracy in writing. As previous research showed (Ferris, 2004) teachers should use different types of feedback and correct different types of errors.

This finding, in terms of students' perception towards teachers' written corrective feedback, was in accordance with (Amara, 2015) about students' perceptions of teacher written feedback. He found that EFL students had a strong 
interest in teacher comments, appreciated the feedback and misinterpreted some teacher feedback comments. This finding was also in line with Ferris (2004) stating that most students need and want to be corrected by their teachers; therefore, error correction cannot be excluded from writing classrooms. In Chandler (2003) study, based mostly on corrections and rewriting, he concluded that teachers should give error correction feedback and require students to make the correction. This was followed by Bitchener, Young, \& Cameron (2005) in their study on the effects of correction.

All in all, the findings of the study were in accordance with (Mahfoodh \& Pandian, 2011), (Bitchener \& Knoch, 2010), (Lee, 2008), (Treglia, 2008), (Elwood \& Bode, 2014), and (Song, Hoon, \& Alvin, 2017). Here, the students' responses showed a positive perception towards written corrective feedback. The students preferred teacher-direct written corrective feedback to correct their errors than other methods of feedback. Moreover, the students believed that written corrective feedback in general improved writing, especially on grammar accuracy and organization.

\section{Conclusion}

The findings revealed that (a) dealing with the perception on students' attitudes toward receiving direct teacher feedback, the majority of participants $(75 \%)$ felt that they agreed to receive direct teacher corrective feedback on language form, content, and organization. Their preference on the area of correction was in language forms (85\%), and the less area of correction was in the organization (65\%). (b) Dealing with the perception on students' feelings toward receiving direct teacher feedback, it was found that most students believed that it was important to receive direct teacher feedback, arguing that they felt satisfied when they got direct teacher feedback (90\%), they preferred to get feedback than no feedback (90\%), their teacher's feedback helped them improved their writing (85\%), they felt assessed when they got teacher's feedback (85\%), and their teacher's feedback made them confident of producing a better draft (90\%). (c) Responses also showed that students, in general, appreciated the teacher's feedback and had a positive attitude towards written corrective feedback. Students' responses showed their preference for direct written corrective feedback. Students considered that direct teacher feedback was helpful and useful for their improvement in writing. To conclude, the students' responses showed a positive perception of written corrective feedback. The students valued feedback and believe that it was an important aspect of EFL writing. The students preferred teacher-direct written corrective feedback to correct their errors than other methods of feedback. The students believed that direct feedback in general improved writing, especially on grammar accuracy and organization. 
The findings proposed some considerations regarding direct teacher's feedback in EFL writing class that might be beneficial for writing teachers. To begin with, the students should be made aware of the importance of receiving feedback. The students' perception on teacher's feedback in the EFL writing class was very important for the teacher to successfully implement direct teacher's feedback. Therefore, EFL writing teachers should explain to the students about the whole procedure. Teachers should determine, which errors they wanted to correct, how they wanted to correct them and when they were planning to make the correction and involved the students so that they could be a part of the process. Finally, EFL teachers should monitor the students during the process of correction in order to observe their language development in EFL writing class. It was also recommended that the teachers plan well and do carefully to implement the teacher's feedback, since the students would get the advantages of teacher's feedback, if it was well planned. As this research was conducted with only 20 EFL writing students, it was not very likely to make generalizations about the findings. Therefore, further researches might work with greater number participants so that they could reach at more generalizable conclusions. Since, this study applied quantitative paradigm, it was recommended that future researchers apply qualitative paradigm to have a deeper analysis on the related topic. Another recommendation for future researcher was to conduct the similar study with a different level of students. Because this study was carried out with university level of students, it was recommended to conduct a similar study with senior high school level of students. 


\section{References}

Amara, T. M. (2015). Learners' perceptions of teacher written feedback commentary in an ESL writing classroom. In International Journal of English Language Teaching (Vol. 3).

Bitchener, J., \& Knoch, U. (2010). The contribution of written corrective feedback to language development: A ten month investigation. Applied Linguistics, 31(2), 193-214. https://doi.org/10.1093/applin/amp016

Bitchener, J., Young, S., \& Cameron, D. (2005). The effect of different types of corrective feedback on ESL student writing. Journal of Second Language Writing, 14(3), 191-205. https://doi.org/10.1016/j.jslw.2005.08.001

Chandler, J. (2003). The efficacy of various kinds of error feedback for improvement in the accuracy and fluency of L2 student writing. Journal of Second Language Writing, 12(3), 267-296. https://doi.org/10.1016/S1060-3743(03)00038-9

Chung, B. (2015). Written corrective feedback: The perception of Korean EFL learners. Pan-Pacific Association of Applied Linguistics, 19(2), 75-88.

Clements, S. J. (2011). Writing conferences in kindergarten: using feedback to enhance student writing. Proquest, Umi Dissertation Publishing.

Ellis, R. (2009). A typology of written corrective feedback types. ELT Journal, 63(2), 97-107. https://doi.org/10.1093/elt/ccn023

Elwood, J. A., \& Bode, J. (2014). Student preferences vis-à-vis teacher feedback in university EFL writing classes in Japan. System, 42(1), 333-343. https://doi.org/10.1016/j.system.2013.12.023

Erkkilä, M. (2013). Teacher Written Feedback: Teachers' perceptions of given feedback Candidate's thesis. University of Jyväskylä.

Evans, N. W., Hartshorn, K. J., \& Allen Tuioti, E. (2010). Written Corrective Feedback: The Practitioners' Perspective. International Journal of English Studies, 10(2), 47. https://doi.org/10.6018/ijes/2010/2/119191

Ferris, D., \& Bitchener, J. (2012). Written Corrective Feedback for L2 Development: Current Knowledge and Future Research. TESOL Quarterly, 46(4), 855-860. https://doi.org/10.1002/tesq.62

Ferris, D. R. (2004). The "Grammar Correction"” Debate in L2 Writing: Where are we, and where do we go from here? (and what do we do in the meantime ...?). Journal of Second Journal of Second Language Writing, 13, 49-62. https://doi.org/10.1016/j.jslw.2004.04.005 
Ferris, D., \& Roberts, B. (2001). Error feedback in L2 writing classes How explicit does it need to be? Journal of Second Language Writing, 10(3), 161-184. https://doi.org/10.1016/S1060-3743(01)00039-X

Hamouda, A. (2011). A Study of Students and Teachers' Preferences and Attitudes towards Correction of Classroom Written Errors in Saudi EFL Context. 4(3). https://doi.org/10.5539/elt.v4n3p128

Jodaie, M., Farrokhi, F., \& Zoghi, M. (2011). A Comparative Study of EFL Teachers' and Intermediate High School Students' Perceptions of Written Corrective Feedback on Grammatical Errors. English Language Teaching, 4(4). https://doi.org/10.5539/elt.v4n4p36

Kartchava, E. (2016). Learners' Beliefs About Corrective Feedback in the Language Classroom: Perspectives from Two International Contexts. TESL Canada Journal, 33(2), 19. https://doi.org/10.18806/tesl.v33i2.1235

Lee, I. (2008). Student reactions to teacher feedback in two Hong Kong secondary classrooms. Journal of Second Language Writing, 17(3), 144-164. https://doi.org/10.1016/j.jslw.2007.12.001

Mahfoodh, O., \& Pandian, A. (2011). A Qualitative Case Study of EFL Students' Affective Reactions to and Perceptions of Their Teachers' Written Feedback. English Language Teaching, 4(3), 14-27. https://doi.org/10.5539/elt.v4n3p14

Martinez Buffa, I. (2016). Written corrective feedback in secondary education: Learners' and teachers' preferences and perceptions. Fòrum de Recerca, (21), 525-546. https://doi.org/10.6035/forumrecerca.2016.21.29

Mustafa, R. F. (2012). Feedback on the feedback: Sociocultural interpretation of Saudi ESL learners' opinions about writing feedback. English Language Teaching, 5(3), 3-15. https://doi.org/10.5539/elt.v5n3p3

Oler, S. O. (2015). EFL Students'Attitudes and Preferences towards Written Corrective Feedback (Universitat Jaume I.). Retrieved from http://hdl.handle.net/10234/134705

Rejab, H. M., Ismail, Z., \& Jamaludin, S. (2015). Teacher's feedback on Arabic student writing process. Mediterranean Journal of Social Sciences, 6(2), 608614. https://doi.org/10.5901/mjss.2015.v6n2p608

Sato, M., \& Lyster, R. (2012). Peer interaction and corrective feedback for accuracy and fluency development. Studies in Second Language Acquisition, 34(4), 591626. https://doi.org/10.1017/S0272263112000356

Sheen, Y. (2007). The Effect of Focused Written Corrective Feedback and Language Aptitude on ESL Learners' Acquisition of Articles. TESOL Quarterly, 41(2), 
255-283. https://doi.org/10.1002/j.1545-7249.2007.tb00059.x

Smalley, R. L., Ruetten, M. K., \& Kozyrev, J. (2012). Refining composition skills : academic writing and grammar. English Language Teaching, 4(3), 128-141. https://doi.org/doi:10.5539/elt.v4n3p128

Song, G., Hoon, L. H., \& Alvin, L. P. (2017). Students' Response to Feedback: An Exploratory Study. RELC Journal, 48(3), 357-372. https://doi.org/10.1177/0033688217691445

Soori, A., Kafipour, R., \& Soury, M. (2011). Effectiveness of different types of direct corrective feedback on correct use of English articles among the Iranian EFL Students. European Journal of Social Sciences, 26(4), 494-501.

Tangkiengsirisin, S., \& Kalra, R. (2016). Thai Students' Perceptions on the Direct Vs. Indirect Written Corrective Feedback: A Thai University Context. (AWEJ), Arab World English Journal, 7(3), 161-176.

Treglia, M. O. (2008). Feedback on Feedback: Exploring Student Responses to Teachers' Written Commentary. Journal of Basic Writing, 27(1), 105-137.

Vyatkina, N. (2011). Writing Instruction and Policies for Written Corrective Feedback in the Basic Language Sequence. In L2 Journal (Vol. 3). Retrieved from http://repositories.cdlib.org/uccllt/12/vol3/iss1/art4/

Westmacott, A. (2017). Direct vs. Indirect written corrective feedback: Student perceptions. Íkala, Revista de Lenguaje Y Cultura, 22(1), 17-32. https://doi.org/10.17533/udea.ikala.v22n01a02

Williams, C. (2007). Research Methods. Journal of Business \& Economic Research, $5(3), 65-72$. 